\title{
POLITIKK
}

SKANDINAVISK TIDSSKRIFT

FOR INTERNASJONALE STUDIER

Årgang 78, Nummer 1, side 106-116, 2020, ISSN 1891-1757, www.tidsskriftet-ip.no, Publisert februar 2020

\author{
FOKUS: KiNESISKE INVESTERINGER I NORDEN
}

\section{Holdninger til utenlandske investeringer fra Kina i de nordiske land ${ }^{\mathrm{I}}$}

\author{
Morten Skumsrud Andersen og Ulf Sverdrup \\ Norsk Utenrikspolitisk Institutt (NUPI)
}

\begin{abstract}
Sammendrag
Hva er holdningene i de nordiske landene til utenlandske investeringer? Spiller det noen rolle for befolkningen hvor de utenlandske investeringene kommer fra? Er man mer skeptisk til utenlandske investeringer innenfor noen sektorer av økonomien, mens man er mindre skeptisk til utenlandske investeringer innenfor andre sektorer? Dette essayet presenterer resultatene fra en omfattende spørreundersøkelse blant befolkningene i alle de nordiske landene.
\end{abstract}

Nøkkelord: økonomi • utelnandske investeringer $\cdot$ Kina

Et viktig spørsmål i debatten om eventuell kontroll og begrensninger knyttet til utenlandske investeringer er spørsmålet om holdninger, legitimitet og folkelig forankring. For å forstå holdningene bedre har vi gjennomført en omfattende spørreundersøkelse blant befolkningene i alle de nordiske landene. Vi ønsket å undersøke holdninger til utenlandske investeringer generelt, og mer spesielt holdningene til investeringer fra henholdsvis EU-land, Kina og Russland. I dette essayet presenterer vi noen av resultatene fra undersøkelsen.

Utenlandske investeringer har de siste tiårene vært gjenstand for relativt få generelle internasjonale reguleringer, og det finnes få eller ingen avtaler, rammeverk, eller organisasjoner tilsvarende WTO for internasjonal investeringsaktivitet. De nordiske land har også vært relativt åpne økonomier, og det har vært et ønske å tiltrekke seg

\footnotetext{
${ }^{1}$ Arbeidet med denne artikkelen er finansiert med støtte fra Nordisk ministerråd og Norges forskningsråd, prosjektnummer 296501.

^Kontaktinformasjon: Morten Skumsrud Andersen, e-post: msa@nupi.no

(C2020 Morten Skumsrud Andersen og Ulf Sverdrup. This is an Open Access article distributed under the terms of the Creative Commons Attribution 4.0 International License (http://creativecommons.org/licenses/by/4.0/), allowing third parties to copy and redistribute the material in any medium or format and to remix, transform, and build upon the material for any purpose, even commercially, provided the original work is properly cited and states its license. Citation: Morten Skumsrud Andersen og Ulf Sverdrup (2020). Holdninger til utenlandske investeringer fra Kina $i$ de nordiske land. Internasjonal Politikk, 78(1): 106-116. http://dx.doi.org/10.23865/intpol.v78.2086
} 
utenlandske investeringer. De nordiske landene har også høstet gevinster av at de har hatt stor adgang til å investere $\mathrm{i}$ andre land. De siste årene har imidlertid internasjonale investeringsmønstre endret seg, først og fremst ved at det er økt flyt av kapital fra land som for eksempel Russland og Kina. Dette mønsteret gjenfinner vi også i de nordiske landene, der kinesiske investeringer har økt betydelig.

Som en respons på dette nye mønsteret har en rekke stater sett nærmere på hvordan de skal håndtere disse investeringene. De har dels forsterket eksisterende tiltak, noen har introdusert nytt lovverk og nye mekanismer for å kunne håndtere utenlandske investeringer, eller de er i ferd med å gjennomføre slike endringer. Sektorene og transaksjonstypene som omfattes av investeringskontroller - eller «screening» av investeringer og oppkjøp - blir stadig utvidet. Enkelte hevder derfor at politikk nå påvirker internasjonale investeringsstrømmer i et omfang som ikke har blitt sett på flere tiår. ${ }^{2}$ Vi ser altså en internasjonal trend der stater, også de med tradisjonelt åpne økonomier, nå er mer tilbøyelige til å intervenere enn før. Men bildet er ikke entydig. I noen land, spesielt utviklingsland, går man fortsatt i retning av mer liberalisering. ${ }^{3}$

I denne vendingen spiller opinionen og holdninger en viktig rolle, ikke minst fordi eventuell investeringskontroll i siste instans må legitimeres og demokratisk forankres. I demokratiske land er det ikke uvanlig at svingninger i opinionens holdninger påvirker politikkutforming. Samtidig kan opinionen også påvirkes av politikken. Samspillet mellom opinion og politikkutforming styrkes når politiske saksfelt blir aktualisert og tematisert. ${ }^{4}$ Kontroll med investeringer kan begrunnes og legitimeres med ulike hensyn. Det kan for eksempel være ønske om å markere suverenitet og sikre nasjonal kontroll, eller det kan være hensyn knyttet til nasjonal sikkerhet, eller det kan tenkes å være knyttet til ulike faktorer som miljø, arbeidsforhold eller styresett og korrupsjonsrisiko.

Som nevnt $\mathrm{i}$ introduksjonen står vi nå trolig foran en ny og viktig rebalansering i det globale økonomiske systemet. På den ene siden står hensynet til en åpen bevegelse av kapital der likebehandlingsprinsippet står sentralt, på den andre står sikkerhet og beskyttelse av kritiske sektorer, der man gjerne gir allierte eller land man har tett sikkerhetspolitisk samarbeid med, en spesiell posisjon. Stater må søke å finne en god balanse mellom å sikre gode vilkår for økonomisk utvikling samtidig som man skal ivareta nasjonale sikkerhetshensyn. For små land som de nordiske reises det en rekke spørsmål om mulighetene og betingelsene for - og hensiktsmessigheten av hva Traavik-utvalget kalte "forebyggende nasjonal sikkerhet». ${ }^{5}$

Dette er bakgrunnen for tre sett med spørsmål vi ser nærmere på i denne artikkelen. For det første: Hva er den generelle holdningen til borgere $i$ de nordiske land til

\footnotetext{
${ }^{2}$ https://www.freshfields.com/49f90b/globalassets/services-page/regulatory-compliance-and-public-law/ pifi-report-final.pdf)

${ }^{3}$ UNCTAD World Investment Report 2018.

${ }^{4}$ Se f.eks. Christopher Wlezien og Staurt N. Soroka (2010). Degrees of Democracy: Politics, Public Opinion, and Policy. Cambridge: Cambridge University Press.

${ }^{5}$ NOU 2016: 19, Samhandling for sikkerhet. Beskyttelse av grunnleggende samfunnsfunksjoner $i$ en omskiftelig tid.
} 
utenlandske investeringer? Er utenlandske investeringer generelt sett betraktet som et positivt tilskudd og noe som ønskes velkommen i de nordiske land, eller er utenlandske investeringer noe man i utgangspunktet er mer negativ og skeptisk til? Er det en manifest eller latent proteksjonisme i befolkningen i de nordiske land, eller er det et ønske om sterkere økonomisk integrasjon på tvers av landegrensene?

For det andre: Spiller det noen rolle for befolkningen hvor de utenlandske investeringene kommer fra? Vi ønsker altså å kartlegge om det finnes variasjon i synet på utenlandske investeringer avhengig av hvilke land eller regioner investeringene kommer fra. Er befolkningen i de nordiske landene rene "globalister», det vil si at de ikke er opptatt av eller skiller vesentlig mellom investorenes opprinnelsesland, eller er de mer «regionalister», det vil si at de har ulik holdning til ulike investorer. Er for eksempel befolkningen i de nordiske land mer positive til investeringer fra land der man har geografisk nærhet og mange og tette økonomiske, politiske og sikkerhetspolitiske bånd, enn til de investorene som er fjernere, og der det er færre og svakere bånd? I undersøkelsen sammenlikner vi derfor hvordan befolkningen i de nordiske land ser på investeringer fra EU-land, Russland og Kina.

For det tredje ønsker vi å undersøke om befolkningen $i$ de nordiske land har en «kategorisk» eller "pragmatisk» holdning til utenlandske investeringer. Er det for eksempel slik at befolkningen er mer skeptisk til utenlandske investeringer innenfor noen sektorer av økonomien, mens man er mindre skeptisk til utenlandske investeringer innenfor andre sektorer? Gjennom å forstå bedre hvorvidt og hvordan holdninger til investeringer varierer mellom sektorer og opprinnelsesland, kan vi også få en bedre forståelse av hva som er årsak og begrunnelse for både positive og negative holdninger til utenlandske investeringer.

Vår undersøkelse er utført av Sentio i august 2019. Utvalget består av 4894 personer over 18 år fra Sverige, Norge, Finland, Danmark og Island, som har respondert som deltakere i et nettpanel (ca. 1000 per land). Resultatene for hvert enkelt land er vektet for å gjenspeile populasjonen med tanke på kjønn, alder og geografi. Feilmarginen i undersøkelsen er standard:Ved verdier som fordeles 10/90, er den på ca. 1,9 prosentpoeng, mens ved 50/50 er den på ca. 3,1 prosentpoeng.

\section{Positive generelle holdninger til utenlandske investeringer}

Vi finner en ganske positiv grunnholdning i de nordiske land til utenlandske investeringer. Andelen som er positive til utenlandske investeringer (31 prosent), er klart større enn andelen som er negative (17 prosent), selv om det er mange som oppgir at de stiller seg avventende og svarer «både og» (39 prosent). Dette mønsteret passer godt med den generelle politiske og økonomiske situasjonen i disse landene, som alle har en åpen økonomi og ganske stor forekomst av utenlandske investeringer og utenlandsk eierskap, samtidig som de har hatt et betydelig innslag av blandingsøkonomi.

Vi finner imidlertid noe variasjon. I Sverige og Danmark er det en noe større andel som oppgir en positiv holdning til utenlandske investeringer. For eksempel er fire av ti svensker positive til utenlandske investeringer, mens kun én av ti er negativ. 
Vi finner noe av det samme mønsteret i Finland og Norge, selv om det her er noen færre som er positive, og noen flere er negative. Island er det nordiske landet som klart skiller seg ut, og her er det en klart større andel som generelt sett er negative til utenlandske investeringer, enn andelen positive. Fire av ti islendinger er generelt sett negative til utenlandske investeringer, mens tre av ti er positive.

Vi kan også observere noe variasjon i holdninger mellom ulike grupper. Vi finner at menn er mer positive til utenlandske investeringer enn kvinner, mens eldre borgere er noe mer negative til utenlandske investeringer enn de yngre. Borgere med høy utdanning og inntekt er mer positive til investeringer enn de med lavere utdanning og lavere inntekt. På tross av at det er en ganske stor andel som er nokså nøytrale («både og») i sin generelle holdning til utenlandske investeringer, peker resultatene samlet sett i retning av at det er en ganske positiv - eller i det minste en positiv/ nøytral - holdning til utenlandske investeringer generelt i de nordiske landene.

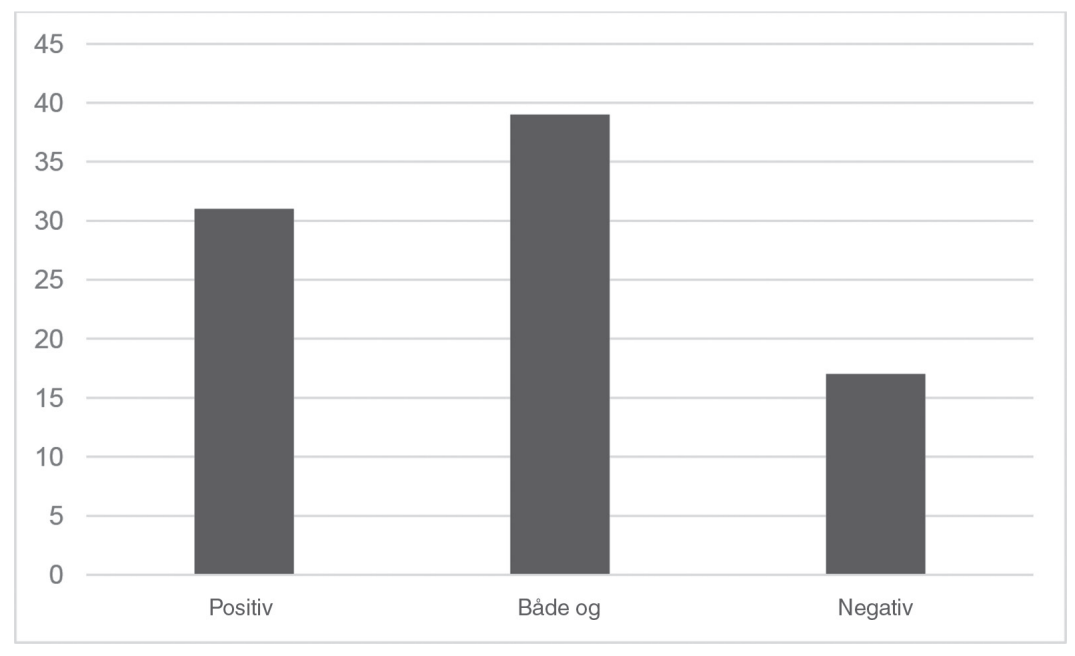

Figur 1 Holdning til utenlandske investeringer. Gjennomsnitt for alle nordiske land $(\mathrm{N}=4894)$. ("Hva er din generelle holdning til utenlandske investeringer i [ditt land].»)

\section{Holdninger til investeringer fra EU-land, Russland og Kina}

Selv om det er en generelt positiv holdning til utenlandske investeringer, finner vi at borgernes holdninger varierer etter investorens opprinnelsesland. Det er store forskjeller i synet på investeringer fra EU-land i forhold til investeringer fra Kina og Russland.

For å sammenligne data har vi indeksert svarene i de ulike nordiske land etter en skala, der $0=$ svært negativ, mens $100=$ svært positiv. Vi finner at det $i$ alle nordiske land er generelt positive holdninger til utenlandske investeringer fra EU-land. Holdningene til investeringer fra EU-land ender på den "positive» siden og har en gjennomsnittlig indeksskår på 55. Det er noe variasjon mellom de nordiske land: I Danmark og Sverige er man mest positive til investeringer fra EU-land (62 i Danmark og 60 i Sverige), mens man på Island har lavest skår (43). 
Det tegnes et annet bilde dersom vi ser på holdningene til utenlandske investeringer fra Kina og Russland. På den samme skalaen er skår for gjennomsnittet i de nordiske landene 34 for investeringer fra Russland, altså klart på den negative enden av skalaen. Det samme finner vi når det gjelder investeringer fra Kina - her er snittskår i de nordiske land 38, altså også klart på den negative siden av skalaen. Dette mønsteret er det samme $i$ alle nordiske land. I samtlige nordiske land er man altså atskillig mer positiv til investeringer fra EU-land enn man er til investeringer fra Russland og Kina. Forskjellene i holdninger er her store og tydelige. Interessant nok finner vi at man $\mathrm{i}$ alle nordiske land er noe mer negative til investeringer fra Russland enn til investeringer fra Kina.

Det er også her noe variasjon i holdningene mellom de nordiske land. Finland er det nordiske landet som er minst negativt til investeringer fra Russland og Kina. I Finland er det heller ikke så stor forskjell på hvordan de vurderer investeringer fra EU-land i forhold til hvordan de ser på investeringer fra Russland og Kina, kun ca. 12 indekspoeng, mens avstanden ligger nærmere 20 indekspoeng i de andre nordiske landene. Dersom vi ser bort fra Island, som har generelt negative holdninger til utenlandske investeringer, er Norge det landet der det er mest negative holdninger til investeringer fra Kina, mens Danmark er det landet der man er mest negativ til investeringer fra Russland.

Opinionen i de nordiske land legger dermed vekt på opprinnelsesland. Det er en ganske positiv holdning til investeringer fra land som er nær, og som man har et tett samarbeid med, herunder innen sikkerhet (EU-landene), mens det er en mer negativ og skeptisk holdning til land man ikke har et sikkerhetssamarbeid med (Russland og Kina). Den klart negative holdningen til kinesiske investeringer som vi kan observere i de nordiske land, er stor, også dersom vi ser til sammenliknbare studier fra ikke-nordiske land. ${ }^{6}$

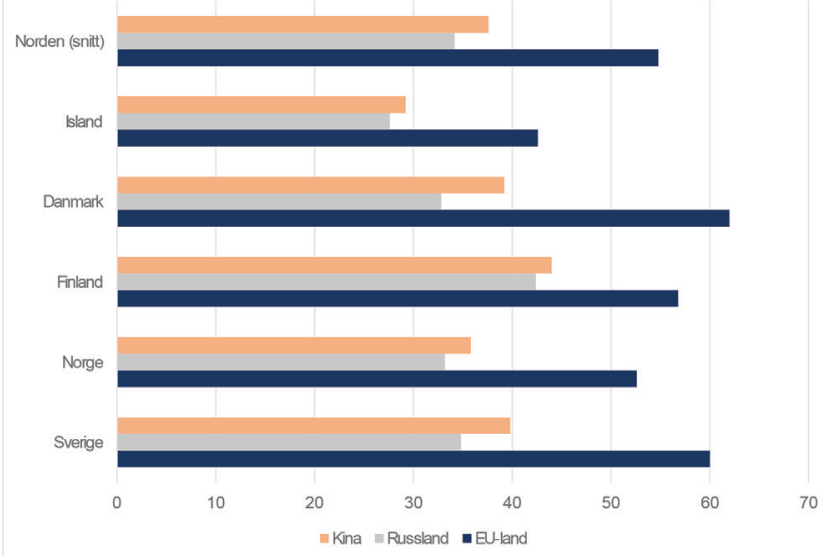

Figur 2 Holdning til utenlandske investeringer, etter opprinnelsesland. Indeks: svært negativ = 0, svært positiv $=100,(\mathrm{~N}=4894)$.

${ }^{6}$ http://angusreid.org/foreign-direct-investment/ 


\section{Holdninger til investeringer innen ulike sektorer}

I denne undersøkelsen har vi også ønsket å kartlegge hvorvidt og hvordan borgere i de nordiske land skiller mellom investeringer fra utlandet innenfor ulike sektorer. Vi ser at borgerne har ulikt syn på ulike investorer med ulike opprinnelsesland, men har de også ulike holdninger til investeringer i ulike sektorer? Vi ba derfor respondentene om å gi sine vurderinger rundt investeringer innenfor følgende fem sektorer: «naturressurser» (for eksempel olje, gass, skog og hav), «infrastruktur» (for eksempel veier, jernbane, havner m.m.), "varehandel», «industri» og "teknologi og telekommunikasjon». I alle de nordiske land har utenlandske investeringer innen disse sektorene vært aktuelle, og disse har blitt møtt med varierende grad av oppmerksomhet. De ulike sektorene har også ulik betydning for landenes økonomi, historie og identitet, og de kan ha ulik betydning for nasjonal sikkerhet, men også for arbeidsplasser, miljø og forbrukerhensyn.

Undersøkelsen viser med all tydelighet at borgerne i de nordiske land skiller mellom de ulike sektorene, og at de gjør ulike vurderinger av om det er ønskelig med utenlandske investeringer fra ulike land i de ulike sektorene. Det mest iøynefallende er hvordan «naturressurser» står i en særstilling. Respondenter i alle land har en klart mer negativ holdning til utenlandske investeringer innen denne sektoren enn innen andre sektorer. På Island er det en særlig negativ holdning til investeringer i «naturressurser», også fra EU-land, men det er også en negativ holdning til investeringer i «naturressurser» fra EU-land i Norge og Finland. På den andre siden av spekteret finner vi "varehandel», hvor holdningene er klart mer positive - ikke bare til investeringer fra EU-land, men her er man også mindre negativ til investeringer fra Russland og Kina.

I mange land har man det siste året hatt økt oppmerksomhet rundt investeringer fra Kina innen telekom og kritisk infrastruktur. Debatten om Huawei i forbindelse med utbyggingen av $5 \mathrm{G}$ har det siste året også vært aktuell i de fleste nordiske land. I den forbindelse er det også interessant å notere at holdningene i alle de nordiske land er ganske negative til kinesiske investeringer innen "teknologi og telekommunikasjon». Men igjen observerer vi noe variasjon; i Finland er man noe mindre negative til kinesiske investeringer i denne sektoren enn $i$ andre nordiske land.

Samlet sett kan man si at befolkningen i de nordiske land skiller mellom både sektorer og investeringsland. I de nordiske landene er man mest negativ til utenlandske investeringer innen "naturressurser» og minst negativ til utenlandske investeringer innen «detaljhandel». De nordiske borgerne rapporterer de klart mest negative holdningene til kinesiske investeringer innen sektorene "naturressurser» og «infrastruktur», mens man er minst skeptisk til kinesiske investeringer innen "detaljhandel» og «industri», men også her er det en negativ grunntone. Vi finner også at borgere i de nordiske land har omtrent de samme negative vurderingene angående investeringer 
fra Russland. Ja, de nordiske borgerne er gjennomgående litt mer skeptiske til russiske investeringer enn til investeringer fra Kina.

Selv om det ikke er store variasjoner mellom de nordiske landene (med unntak av Island), er det variasjon mellom ulike grupper innad i landene. Vi finner imidlertid liten effekt av inntekt, kjønn og utdanning. Men interessant nok observerer vi gjennomgående at de unge borgerne, særlig de under 35 år, er vesentlig mindre skeptiske til investeringer fra både Kina og Russland enn gjennomsnittet. De unge er mildt positive til investeringer fra Kina innen "varehandel», «infrastruktur», "teknologi og telekom» og «industri», og de er heller ikke særlig negative til investeringer fra Kina innen "naturressurser", på tross av en ellers ganske sterk skepsis i befolkningen som helhet. Den samme aldersgruppen er også signifikant mindre skeptisk enn eldre velgere til investeringer fra Russland innen de samme sektorer. I hele vårt materiale finner vi i det hele tatt ingen bakgrunnsvariabel som kan forklare variasjonen i holdninger til utenlandske investeringer så systematisk som alder. Unge voksne er langt mindre negative til kinesiske og russiske investeringer i alle sektorer.

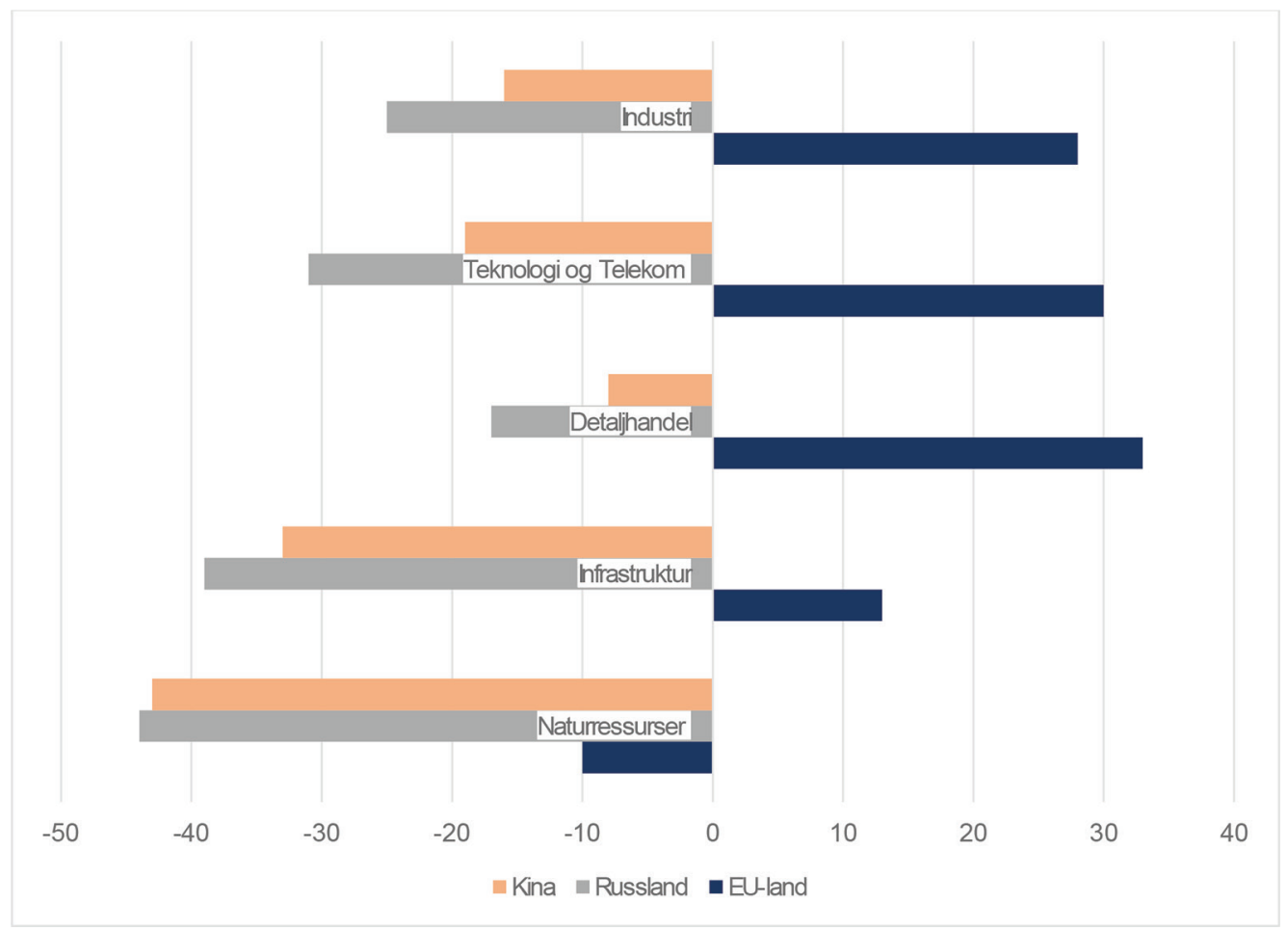

Figur 3 Holdninger til investeringer fra ulike land innen ulike sektorer (andel positive minus andel negative) $(\mathrm{N}=4894)$. ("Hvordan stiller du deg til investeringer fra [land] innen følgende sektorer.») 


\section{Litt om årsaker til negative holdninger til kinesiske investeringer}

I undersøkelsen ønsket vi også å forsøke å forstå bedre hva som kan være årsaken til negative holdninger til kinesiske investeringer i de nordiske landene. I fagdebatten og i det politiske ordskiftet trekkes ofte flere faktorer frem. Vi ba derfor de 2934 av de 4894 (altså ca. 60 prosent) som hadde oppgitt at de var negative til kinesiske investeringer, om å gi en begrunnelse for hvorfor de hadde slike holdninger. Respondentene kunne oppgi en eller flere av følgende faktorer: knyttet til suverenitet («tap av kontroll med nasjonale ressurser»), arbeidslivsforhold og miljø ("dårligere arbeidsvilkår» og «negative miljøeffekter»), påvirkning på samfunnsmodell ("korrupsjon») og effekt på nasjonal sikkerhet ("sikkerhetsrisiko»). Respondentene kunne også oppgi andre faktorer, men det var det få som gjorde.

De fleste respondentene oppga at hovedårsaken til at de hadde negative holdninger til kinesiske investeringer, var knyttet til suverenitet og «tap av kontroll med nasjonale ressurser» (67 prosent). «Sikkerhetsrisiko» var den faktoren som nest flest fremhevet (49 prosent). Deretter kom "korrupsion» (43 prosent), "negative miljøeffekter» (42 prosent) og til sist «dårligere arbeidsvilkår» (34 prosent).

Vi finner også her variasjon mellom ulike nordiske land. I Sverige og Finland er det rundt 60 prosent som oppgir at de frykter «tap av kontroll med naturressurser», mens denne frykten er enda sterkere i Norge og Island, henholdsvis 70 og 77 prosent. Enda større er forskjellene i vurderinger rundt "sikkerhetsrisiko». Norge er det landet der klart flest oppgir at "sikkerhetsrisiko» er årsaken til at de er negative til kinesiske investeringer (65 prosent), men en stor andel i Sverige og Danmark oppgir også denne faktoren (ca. 55 prosent). I Finland er det mindre bekymring rundt «sikkerhetsrisiko» (46 prosent), mens på Island er den nærmest fraværende, der bare 26 prosent oppgir «sikkerhetsrisiko» som begrunnelse for sine negative holdninger til kinesiske investeringer.

I Finland er det derimot en særlig høy andel som oppgir at deres skepsis til kinesiske investeringer er knyttet til faren for «negative miljøeffekter» (58 prosent), mens det er langt færre nordmenn som legger vekt på denne faktoren (32 prosent). Igjen finner vi liten variasjon i holdningene mellom ulike inntektsgrupper, men vi finner interessant variasjon mellom ulike aldersgrupper. Blant de yngste respondentene, (de mellom 18 og 22 år) er «negative miljøeffekter» den klart viktigste grunnen til at de er negative til kinesiske investeringer ( 57 prosent). De unge fremhever også frykten rundt "dårligere arbeidsvilkår», mens det er først på tredje- og fjerdeplass at vi finner hensyn til suverenitet og kontroll med naturressurser eller sikkerhetsrisiko. Det er i det hele tatt signifikante og markante forskjeller i datamaterialet mellom de yngste og de eldste med tanke på hvilke faktorer de oppgir som årsak til negative holdninger. Mens de unge legger vekt på miljø og arbeidsmiljø, legger de eldre mer vekt på suverenitet og sikkerhet. 


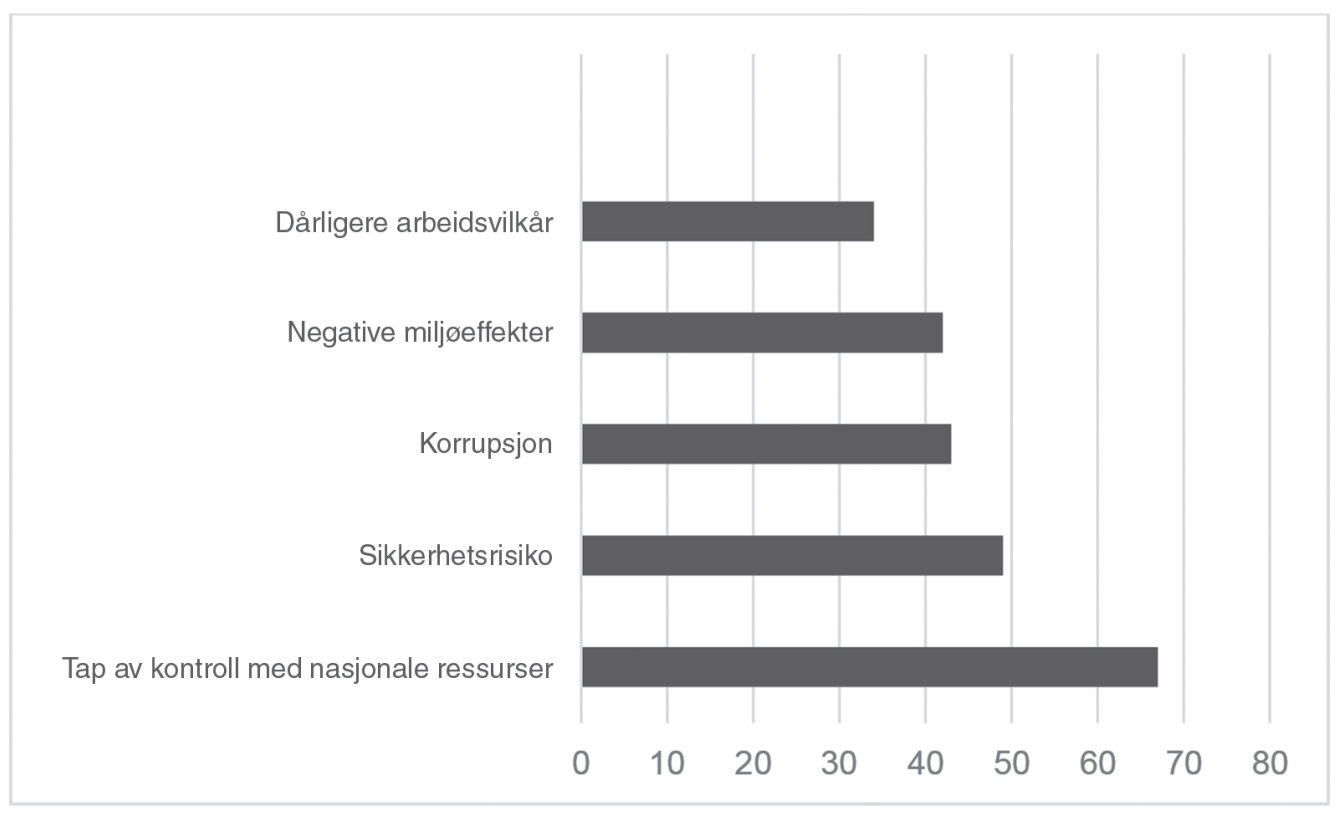

Figur 4 Årsak til negativ holdning til kinesiske investeringer. Frekvens i prosent $(\mathrm{N}=2934)$. («Hva er hovedårsaken til at du er negativ til kinesiske investeringer i [ditt land]? Flere alternativer mulig.»)

\section{Konklusjoner}

Det er særlig tre hovedfunn som er viktige å fremheve i denne omgang:

Vi finner en mildt positiv generell grunnholdning til utenlandske investeringer i alle nordiske land. Disse er alle små, åpne økonomier som effektivt har nyttiggiort seg globaliseringen, og holdningene synes å gjenspeile dette.

Vi observerer også at investorens opprinnelsesland påvirker hvordan man vurderer utenlandske investeringer. I alle land skiller man klart mellom utenlandske investeringer fra allierte og investeringer fra ikke-allierte. Vi finner en klart positiv holdning til utenlandske investeringer fra EU-land, mens det er en utbredt skepsis og negativ holdning til investeringer fra Russland og Kina. Det nordiske publikum er dermed ikke uforbeholdne "globalister", de er snarere "regionalister» - eller globalister med forbehold og bevissthet rundt balansen mellom en åpen økonomi og ivaretakelse av nasjonale interesser.

Endelig viser undersøkelsen også at befolkningen i de nordiske land skiller klart mellom hvordan de vurderer utenlandske investeringer innenfor ulike sektorer og områder av økonomien. Der hvor befolkningen er skeptisk, er de ikke kategorisk avvisende til alle investeringer som sådan, men er i noen grad pragmatiske og skiller mellom investeringer i ulike sektorer. Et unntak kan sies å være utenlandske investeringer i naturressurser. Her finner vi en betydelig skepsis i alle land, mens det er mer sammensatte og nyanserte holdninger til investeringer innen andre sektorer. 
Undersøkelsen viser også at befolkningens syn på investeringer innenfor ulike sektorer varierer med investorens opprinnelsesland. Holdningene til investeringer fra Kina innen detalihandel er for eksempel mer positive enn holdningene til kinesiske investeringer innen naturressurser eller infrastruktur.

I undersøkelsen observerer vi betydelig konvergens og likhet i vurderingene $\mathrm{i}$ de ulike nordiske land. Mønsteret er det samme i alle land, det har litt ulik valør og styrke, men retningen og tendensen er den samme $i$ alle land. Det er samtidig noen interessante variasjoner mellom grupper innad i de ulike nordiske land. Et særlig påfallende mønster er at unge borgere rapporterer avvikende syn fra giennomsnittet. De unge er gjennomgående mer positive til investeringer generelt, og de er også mindre negative til investeringer fra Kina og Russland. Når de er skeptiske, knyttes denne skepsisen ikke primært til sikkerhet eller naturressurser, som i den øvrige befolkningen, men snarere fremhever de unge særlig risiko knyttet til miljø.

De andre bidragene i denne spalten har vist at de fleste nordiske land nå er $\mathrm{i}$ ferd med se nærmere på hvorvidt og hvordan de skal søke å regulere og håndtere eventuell risiko knyttet til endret mønster av utenlandske investeringer, spesielt når det gjelder kinesiske investeringer. Det er derfor naturlig å spørre hvilke lærdommer man eventuelt kan ta med seg fra denne opinionsundersøkelsen i den refleksjonsprosessen de nordiske land nå står $\mathrm{i}$. I utviklingen av politikk på området vil det naturligvis være mange hensyn å ta, men dersom holdningene i befolkningen spiller en rolle, peker tre forhold seg særlig ut:

For det første er det nærliggende å tro at det kan være gevinster knyttet til samarbeid og koordinering blant de nordiske land, og det vil uansett være slik at nordiske lands regimer og begrunnelser vil ha betydning for de andre nordiske landenes politikkutforming. Resultatene fra denne undersøkelsen peker i retning av at det er et noenlunde likt holdningsmønster og en felles nordisk tilnærmingsmåte. Befolkningen i alle nordiske land er relativt åpne for utenlandske investeringer på generelt grunnlag, de skiller mellom investeringer fra EU-land, Kina og Russland, og de skiller mellom sektorer. Befolkningen gjør altså nokså like vurderinger, om enn med litt ulik styrke. Unntaket er Island, men også her følger befolkningen stort sett den generelle trenden. Felles holdninger og virkelighetsforståelse kan bidra til å giøre samarbeid og koordinering innad i Norden lettere, for eksempel når det kommer til eventuelle regimer for investeringskontroll.

For det andre, selv om det er en mildt positiv holdning til utenlandske investeringer, er det også klart at det finnes det finnes en latent vilje til proteksjonisme i de fleste land, ikke minst når det gjelder visse sektorer av økonomien og overfor visse land. Samtidig er det en viss internasjonal trend i retning av å utvide sikkerhetsbegrepet og styrke ulike mekanismer for investeringskontroll, ofte etter innenrikspolitisk press. Fra et politisk perspektiv må vi forvente at det kan være krevende å sikre investeringsregimer som er ikke-diskriminerende. Og det kan være krevende å balansere mellom det å, på den ene siden, ivareta sikkerhetsinteresser i de tilfellene der en investering utgjør en åpenbar risiko, samtidig som man, på den andre siden, unngår 
å ende opp med uønsket proteksjonisme - eller et inntrykk av proteksjonisme - ved at hensyn til sikkerhet brukes $i$ en svært utvidet forstand som påskudd for å oppnå andre politiske målsettinger eller prioriteringer. Økt digitalisering gjør det også stadig vanskeligere å trekke klare skiller mellom sektorer der det er særlig viktig å sikre nasjonal kontroll, og sektorer der det er ønskelig å ha åpenhet.

For det tredje må de nordiske land i politikkutformingen også søke å lage løsninger som håndterer de truslene som befolkningen opplever og fremhever. Samlet sett er det ønsket om kontroll med naturressurser og frykten for at investeringer skal innebære en sikkerhetsrisiko som særlig fremheves som årsak til negative holdninger til kinesiske investeringer. Mens vi samlet sett observerer relativt små forskjeller mellom de nordiske land i hvordan de fremhever trusselvurderingene, finner vi også et ganske tydelig og sterkt fremtredende skille mellom ulike generasjoner på tvers av de nordiske land. De unge voksne trekker linjer mellom sikkerhet og investeringer på andre og nye måter enn de som er noe eldre, og dette kommer særlig uttrykk i hvordan de begrunner sine negative holdninger til kinesiske investeringer $i$ en frykt for negative miljøeffekter snarere enn i sikkerhet i mer tradisjonell forstand. At det er så vidt store ulikheter på tvers av generasjoner i trusselvurderingene, kan representere en utfordring i utformingen av veltilpassede regimer for kontroll med utenlandske investeringer.

\section{Om forfatterne}

Ulf Sverdrup er direktør ved Norsk Utenrikspolitisk Institutt (NUPI). Han har en doktorgrad i statsvitenskap fra Universitetet i Oslo. Før han begynte ved NUPI, var han professor ved Handelshøyskolen BI og professor ved ARENA Senter for europaforskning ved Universitetet i Oslo. Sverdrup står bak en rekke publikasjoner om ulike tema innen internasjonal politikk, med særlig vekt på europeisk politikk, europeisk integrasjon og norsk utenrikspolitikk. Han ledet sekretariatet for Europautredningen (NOU 2012:2).

Morten Skumsrud Andersen er seniorforsker ved Norsk Utenrikspolitisk Institutt (NUPI), hvor han blant annet jobber med prosjektet "Consequences of Investments for National Security (COINS)» som studerer hvordan utenlandske investeringer kan påvirke samfunnssikkerhet og internasjonal politikk.

\section{Abstract in English \\ Attitudes to Direct Investments from China in the Nordic Countries}

How does the Nordic public view foreign investments? Does the country of origin for such investments matter for the public? Would the public be more critical of investments into certain sectors of the economy, whilst being less critical to foreign investments in others? This essay presents the results from an extensive survey of public opinion conducted across all the Nordic countries.

Keywords: economy $\cdot$ foreign investments $\cdot$ China 